


\title{
Signs of a Legal Entity of Public Law under the Legislation of Ukraine
}

\author{
DOI: https://doi.org/10.46398/cuestpol.3969.24
}

\author{
V. F. Poddubnaya *
}

A. M. Yevkov **

Yu. M. Filonova ***

\begin{abstract}
The article examines the legal status of legal entities of public law as participants in civil circulation. Both general and special research methods were used, which were determined by the purpose of the article, taking into account the object and subject of the research. To study the above-mentioned civil law relations in their interconnection and development, the dialectical method was used. The comparative legal method was used to analyze the world experience of legal regulation of the status of legal entities of public law in foreign legislation and the doctrine of law, in particular, in the legislation of the CIS countries. Results showed that legal entities of public law are organizations; as legal entities; have the characteristics of a legal entity: organizational unity, the presence of separate property, acting in circulation on their own behalf, independent civil liability. In addition to the general features of a legal entity, legal entities of public law also have special features that characterize them as participants in civil turnover. It was concluded that legal entities of public law are a type of legal entity, are created in the administrative order by the
\end{abstract} state and have targeted legal capacity.

Keywords: legal person under public law; organization; public interest; legal capacity; legislation of Ukraine.

* Candidate of Legal Sciences (Ph.D), Associate Professor of the Department of Civil Law No. 2 of the National Law University named after Yaroslav the Wise, Kharkiv, Ukraine. ORCID ID: https://orcid. org/oooo-0002-1139-9796. Email: global@ores.su

** Candidate of Legal Sciences (Ph.D), Associate Professor of the Department of Civil Law No. 2 of the National Law University named after Yaroslav the Wise, Kharkiv, Ukraine. ORCID ID: https://orcid. org/oooo-0oo1-8777-5121. Email: global@prescopus.com

*** Postgrad student of the Department of Civil Law No. 2 of the National Law University named after Yaroslav the Wise, Kharkiv, Ukraine. ORCID ID: https://orcid.org/oooo-0oo2-1361-0145. Email: info@prescopus.com

Recibido el 03/03/2021 Aceptado el 22/05/2021 


\section{Signos de una entidad jurídica de derecho público en virtud de la legislación de Ucrania}

\section{Resumen}

El artículo examina la situación jurídica de las personas jurídicas de derecho público como participantes en la vida civil. Se utilizaron métodos de investigación, tanto generales como especiales, los cuales fueron determinados por el propósito del artículo, tomando en cuenta el objeto y tema de la investigación. Para estudiar las relaciones de derecho civil antes mencionadas en su interconexión y desarrollo, se utilizó el método dialéctico. El método jurídico comparado se utilizó para analizar la experiencia mundial de regulación jurídica del estatus de las personas jurídicas de derecho público en la legislación internacional y la doctrina del derecho, en particular, en la legislación de los países de la CEI. Los resultados mostraron que las personas jurídicas de derecho público se identifican por: ser personas jurídicas; tener las características de una persona jurídica: unidad organizativa, presencia de propiedad separada, actuar por cuenta propia, responsabilidad civil independiente. Además de las características generales de una persona jurídica, las personas jurídicas de derecho público también tienen características especiales como ser participantes en la facturación civil. Se concluyó que las personas jurídicas de derecho público son un tipo de persona jurídica, son creadas en el orden administrativo por el Estado y tienen capacidad jurídica focalizada.

Palabras clave: persona jurídica de derecho público; organización; interés público; capacidad jurídica; legislación de Ucrania.

\section{Introduction}

Today, legal entities of public law are participants in civil circulation in Ukraine. The construction of a "legal entity of public law" was enshrined in the 2003 Civil Code of Ukraine (Haliantych, 2013). The introduction of this construction into the legislation was because the legislator adopted the traditions of the continental system of law in which legal entities are divided into legal entities of private law and legal entities of public law. In addition, the factors that influenced the consolidation of this classification of legal entities were the need to reform the public sector of the economy, the establishment of legal equality of participants in property relations.

It was meant to determine the legal status of subjects of public law, in particular, the state, local government bodies, state-owned enterprises. In the science of civil law, there are no theoretical developments of the concept 
of "legal entity of public law". Most scholars oppose the consolidation of this classification at the legislative level, in particular in Russia, Kazakhstan it was refused to specify the division of legal entities into legal entities of private law and legal entities of public law. Therefore, there are legal problems of determining the legal capacity of legal entities under public law, their types, property independence, and civil liability for their obligations. The question of the criterion for legal entities differentiation into private and public remains debatable in the doctrine. All these problems require a study of the legal status of legal entities of public law as participants in civil legal relations.

The term "legal entity of public law" originated over 200 years in France during the construction of an administrative state. Gradually, from the end of the 19th century, this term began to be used in many European countries, and already in 1990, it was fixed in the Civil Code of Germany. In the doctrine of German law, legal entities of public law are legal entities that are established by virtue of law or administrative act as executors of tasks of a public nature (Ennektserus, 1949). From this concept, two criteria of differentiation of legal entities of public law and private law can be identified. The first criterion: the procedure for the establishment of a legal entity of public law (administrative), a legal entity of private law is created in a regulatory-declarative order; the second criterion: the purpose of the functioning of a legal entity of public law is the performance of public tasks, whereas a legal entity of private law is created to satisfy private interests.

The legal status of legal entities under public law in Germany is determined at the level of public law or the law of individual states (lands). The types of legal entities under public law include the following: legal entities that hold public power in a certain territory - a federation, federal lands, communities; state universities; professional associations (chambers of lawyers, chambers of commerce and industry); federal radio; public law institutions: land radio stations, savings banks, public law funds. Legal entities of public law carry out activities for serving the state and public interests (Adarchenko, 2012).

In France, legal entities of public law include a public institution. The legal status of the latter is characterized by the following features: 1) is a legal entity; 2) is classified as a legal entity of public law; 3) manages the public service. A public institution has property that belongs to it by right of ownership, operates on the principle of specialization, i.e., it has powers and competence only in the area that belongs to its type of activity and is determined by law and regulations. Public institutions are endowed with power and the ability to make decisions and carry out official actions. In French doctrine, public institutions are classified according to different criteria. Therefore, state, and non-state public institutions are distinguished. The state ones include those that act with the aim of 
realizing the state interest, non-state ones - those that operate in a certain territory, in particular communal institutions. Depending on the nature of their activities, the following types are distinguished: public educational institutions (faculties, lyceums, and schools), social institutions (hospitals, charitable institutions), financial institutions (savings banks) (Vatel, 2012).

Thus, an analysis of the legislation of Western countries shows that the concept of "legal entity of public law" is applied to a wide range of different subjects, and there are no criteria for distinguishing between legal entities of public law and legal entities of private law. Unlike Ukrainian legislation, the state and other subjects of public law are recognized as legal entities of public law. According to the Civil Code of Ukraine, the state, the Autonomous Republic of Crimea, territorial communities are not legal entities; they are called subjects of public law and are participants in civil relations (Haliantych, 2013). The main features of a legal entity of public law in Western countries include the following: 1) established by subjects of public law; 2) are created in an administrative order; 3) act for performing public tasks; 4) have the powers of authority and the ability to issue regulations.

The concept of "legal entity of public law" is enshrined in the legislation of the former Soviet republics, in particular, in the civil codes of Georgia, Azerbaijan, Moldova, and the Baltic countries. So, for example, in accordance with Art. 1509 of the Civil Code of Georgia, legal entities of public law include: the state, local self-government, legal entities created by the state on the basis of a legislative or administrative act, which are not created in the organizational and legal forms defined by the Civil Code or the Law of Georgia "On Entrepreneurs", state institutions and foundations, non-state organizations (political parties, religious associations) (Gvelesiani, 2011: 234).

A special law "On Legal Entities of Public Law" is in force in Georgia, according to which a legal entity of public law can be created based on a law, a decree of the President of the country, an administrative act of a public administration body in cases expressly provided by law (Baade, 1995). A legal entity has the right to carry out entrepreneurial activity, but only in the form of an additional one. Legal entities of public law in Georgia can act based on membership, that is, have a corporate structure. There is no specific list of legal entities under public law in Georgian legislation. In the Republic of Moldova, the Civil Code (hereinafter referred to as the " $\mathrm{CC}$ RM") establishes the division of legal entities into public and private, which act in civil legal relations on an equal footing (Cazac, 2020).

The Civil Code of the Republic of Azerbaijan (hereinafter referred to as the CC RA) provides for the differentiation of legal entities into types, among which there are legal entities that carry out activities of state or public importance (public legal entities) (Dadashov, 2020). A legal entity 
of public law can be created by the state, by a municipality body, acquire legal capacity from the moment of state registration, which has a targeted character, acts on the basis of the charter, bankruptcy proceedings cannot be applied to these legal entities. The property of a legal entity of public law can be formed by contributing to the statutory fund, which is created at the expense of the property transferred by the founders, at the expense of funds allocated from the state and local budgets, donations, grants and other sources (Vandenbergh, 2005). The state and municipalities in Azerbaijan are legal entities, but do not belong to legal entities of public law (Mamedov, 2011).

Thus, the general features of legal entities of public law under the legislation of the considered CIS countries are as follows: 1) are created in the administrative order by the state or local government; 2) have a targeted legal capacity - the implementation of state or public interests. In modern law, there is no consensus among scholars about the effectiveness and usefulness of the structure of a legal entity of public law. There are both supporters of consolidation of the "legal entity of public law" concept in doctrine and legislation, and opponents.

In the doctrine of law, there are several approaches to determining the legal nature of a legal entity. So, for example, Bobkova and Ryabchenko (2015), considers the combination of administrative and economic functions in the activities of a given legal entity, the presence of special legal capacity, the impossibility of realizing their public interest with an exclusively commercial nature of activity as the main elements of the legal capacity of legal entities of public law (Wilson, 2002). In the legal literature, a definition of a legal entity of public law is given, which is understood as an organization that is created as a legal entity by the state through the adoption of a public law act, has legal capacity, is endowed with public law powers and property (Vandenbergh, 2005). The special features of a legal entity of public law include the public nature of goals, the presence of power, and the special nature of membership (Tarasov, 2010). All the characteristics of a legal entity are inherent in legal entities of public law: organizational unity, property isolation, civil liability, acting in circulation on its own behalf.

In the science of civil law, organizational unity is understood as a certain hierarchy, subordination of governing bodies (individual and collegial), which make up its structure and in a clear regulation of relations between its participants (Puniyani, 2020). Legal entities of public law have their own structure of bodies that exercise the dispositive capacity (legal capacity to act) of these entities. They carry out their activities based on constituent documents, which are usually adopted by the founder of a legal entity of public law - a subject of public law (Vandenbergh, 2005). So, for example, in accordance with Part 1 of Art. 4 of the Law "On Central Executive Bodies" 
dated March 17, 2011 No. 3166-VI, ministries and other central executive bodies are legal entities of public law (Hood and James, 1997; 188). One of the central executive bodies with a special status is the State Property Fund of Ukraine. The legal status of the State Property Fund of Ukraine is fixed at the level of the special Law of Ukraine "On the State Property Fund of Ukraine" dated 09.12.2011 No. 4107-VI (Maksymenko and Melikhova, 2017: 64).

The State Property Fund of Ukraine is a legal entity of public law that implements state policy in the field of privatization, lease, use and alienation of state property, management of state property, including the corporate rights of the state regarding state property that belong to the sphere of its management, as well as in the field of public administration of property appraisal, property rights and professional appraisal activities. Financing, material and technical support of the State Property Fund of Ukraine is carried out at the expense of the State Budget of Ukraine. The State Property Fund of Ukraine issues orders that are binding on central executive bodies, institutions, enterprises, organizations of all forms of ownership and citizens.

\section{Results and Discussion}

The presence a legal entity's separate property means that this property is separate from the property of the owners who created this organization, from the state, from other subjects of civil law (Puniyani, 2020). As a rule, legal entities of public law are not the owners of the property they have. So, in accordance with Art. Art. 167-169 of the Civil Code of Ukraine, legal entities established on the state or communal form of ownership are legal entities of public law (Haliantych, 2013, 244). Legal entities of public law have their property on limited property rights: the right of operational management, the right of full economic management, which are enshrined at the level of the Economic Code of Ukraine. Today we need to look for an effective alternative to limited property rights, since with the transition of the domestic legal order from outdated structures of unitary enterprises and institutions that do not own their property to normal market relations (the structure of a legal entity - the owner), limitation of the liability of autonomous and budgetary institutions as subjects of civil turnover, as well as the possibility of the founder's interference in the transactions of his own independent legal entity should be gradually eliminated (Ulbashev, 2019).

One of the signs of a legal entity is its ability to take part in civil legal relations, which is expressed in the ability to have, exercise property and non-property rights and perform duties. Legal entities of public law are participants in civil relations. Legal entities of public law in civil relations 
are subject to the provisions of the Civil Code of Ukraine, unless otherwise provided by law (Haliantych, 2013).

The sign of independent property liability is important, since the creation of legal entities has long pursued the goal of maximum elimination of founders (participants, shareholders) from liability based on the results of the use of their invested capital. In accordance with Art. Ninety-six of the Civil Code of Ukraine, a legal entity is independently responsible for its obligations (Haliantych, 2013: 43). A legal entity is liable for its obligations with all of its property. A participant (founder) of a legal entity is not liable for the obligations of its participant (founder), except for cases established by the constituent documents and the law. The liability of legal entities under public law has certain specific features. Therefore, in the Civil Code of Ukraine (Art. 167), among the types of legal entities of public law, state enterprises are called (Haliantych, 2013).

Can all state-owned enterprises act as legal entities of public law? In the opinion of most scientists, state and utility companies can be classified as legal entities of private law, since their activities are not related to the functions of state administration and local self-government but are aimed at a more traditional civil law goal - making a profit, thus most of the state enterprises seek to satisfy private and not public interest. Signs of public interest in the doctrine of law are: 1) compliance with the needs, goals of the whole society and the state, protection by specialized entities (state, public associations); 2) legality, public interest is enshrined in legislation and complies with it; 3) the inadmissibility of restricting public interest, but at the same time, public interest may restrict private one. Therefore, the classification of these entities as legal entities of public law may be based because these participants in civil legal relations depend on their founder, which is the state or local self-government, and the property of these enterprises is state or communal property.

\section{Conclusions}

An analysis of the experience of legal regulation of legal entities of public law in Western countries and the CIS countries shows that legal entities of public law have common characteristics of a legal entity, such as organizational unity, the presence of separate property, independent civil liability, acting in circulation on its own behalf. In addition, these entities also have special features that characterize them as legal entities of public law: first, they are created by subjects of public law (state, local self-government); secondly, they are created in an administrative order; thirdly, the activities of legal entities of public law are aimed at satisfying the state (public) interest; fourthly, legal entities of public law are not the 
owners of the property, the property belongs to the said entities on limited property rights (the right of operational management, the right of full economic management); fifthly, subsidiary responsibility for the actions of a legal entity of public law is borne by the subject of public law, which created the specified entity. Thus, on the basis of the above, it is possible to formulate the concept of a legal entity of public law, which is understood as an organization that is created by a subject of public law, acts on the basis of an administrative act, has legal capacity, which is determined by certain public law purposes, has public law powers, has property, which has a targeted nature for the implementation of these powers.

\section{Bibliographic References}

ADARCHENKO, O. E. 2012. Legal Entities of Public Law: Their Place in Administrative Law. Administrative and municipal law. Vol. 12, pp. 4447.

BAADE, Hans W. 1995. «The Operation of Foreign Public Law» In: Tex. Int'l LJ, p. 429.

BOBKOVA, E. YU; RYABCHENKO, O. N. 2015. Reflection of the problems of legal regulation of intellectual property for objects created in educational institutions in modern legal literature (on the materials of the national bibliographic database of scientific citation). In the World of Scientific Discoveries / V Mire Nauchnykh Otkrytiy, 68 .

CAZAC, Octavian. 2020. Introduction of trusts into the Civil Code of the Republic of Moldova: The Decisive Role of the DCFR. Available at SSRN 3811514 .

ENNEKTSERUS, Louis. 1949. Kurs germanskogo grazhdanskogo prava (The course of German civil law). Translated from German. Izdatel'stvo. Moscow, Russia.

DADASHOV, Emin Teyyub. 2020. Norms Regulating Real Estate Issues In The Civil Code Of The Azerbaijan Ssr Dated September 11, 1964. In: Теоретические Аспекты Юриспруденции И Вопросы Правоприменения, pp. 188-192.

GVELESIANI, Irina. 2011. «Terms Related to the "Trust" in Georgian, Russian and English Languages (according to "The Civil Code of Georgia","The Civil Code of Russian Federation" and "Montana Code")» In: Bilingual Scholarly Peer-Reviewed Journal Spekali. 
HALIANTYCH, M. 2013. «The Value of the Civil Code of Ukraine of 2003 in the Legal Regulation of Housing Relations» In: Private Law/Pryvatne Pravo. Vol. 2.

HOOD, Christopher; JAMES, Oliver. 1997. «The central executive» In Developments in British Politics 5, pp. 177-204. Palgrave. London, UK.

PUNIYANI, Riya. 2020. «Uniform Civil Code and Conflicts of Personal Laws.» Available at SSRN 3643457.

MAKSYMENKO, Iryna; MELIKHOVA, Tatyana. 2017. "Accounting and analytical procurement of state financial control and directions of its implementation in Ukraine» In: Baltic Journal of Economic Studies. Vol. 3, No. 5, pp. 268-275.

MAMEDOV, Z. A. 2011. "Topical problems of Azerbaijan notary service" In: Law and Politics. Vol. 9, pp. 1446-1453.

TARASOV, O. I. 2010. On the Distinction of Private Law and Public Law Relations with the Participation of Legal Entities of Public Law. Vestnik Saint Petersburg UL, 76.

ULBASHEV, A. 2019. "A Citizen in Civil Law (a Historic and Private Law Essay” In: Istoriya. Vol. 10, No. 6, p. 80.

VANDENBERGH, Michael P. 2005. «The private life of public law» In: Colum. L. Rev. Pp. 105, 2029.

VATEL, A. Y. 2012. "Administrative and aesthetic standards in the system of civil service in foreign countries" In: Police activity. Vol. 2, pp. 18-26.

WILSON, E. 2002. Est'zakon, est'i svoy zakony: Legal and Moral Entitlements to the Fish Resources of Nyski Bay, Norht-Eastern Sakhalin. People and the land: Pathways to reform in post-Soviet Siberia, 149-168. 
Vol. 39 N $^{\circ} 69$

Esta revista fue editada en formato digital y publicada en julio de 2021, por el Fondo Editorial Serbiluz, Universidad del Zulia. Maracaibo-Venezuela 